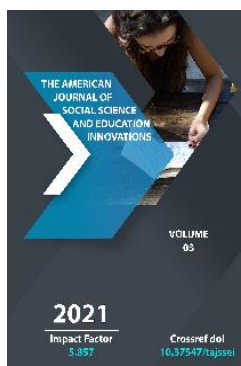

\title{
Developing Personal Creativity: Important Theoretical Ideas And The Chronology Of Their Formation
}

Ibodatkhon Makhmudova

Teacher Of English In The Chair Of The English Language, Ferghana State University, Uzbekistan

\section{ABSTRACT}

The problem of developing person's creative abilities has a special place in the history of the development of pedagogical ideas. Teaching a person to develop creative thinking is carried out on the basis of his creative abilities. Therefore, the idea of Graham Wallace underlies the theory of the development of person's creativity. The idea is based on the fact that the process of creative activity is the four-stage process. Dozens of new views have been advanced more than a hundred years after Wallace's idea. As a result, was formed a theory of developing creative abilities of the individual. The article discusses important ideas of the theory of developing creative abilities of the individual and the chronology of their formation.

\section{KEYWORDS}

Creativity, creative ability, development, students, chronology.

\section{INTRODUCTION}

Globally, natural resource reserves are dwindling. This situation in itself highlights the need to create alternative resources in all spheres of public life. The only effective way 
to create alternative resources is to create human capital and use it wisely. Countries with economic potential today have nearly half a century of experience in creating human capital.

At the same time, Uzbekistan is also a person in the strategic development of society capital creation - the search for talented young people, serious attention is paid to ensuring their quality education. According to V.V. Moroz, the application of a creative approach to the educational process provides the most important resource - the maximum activation of human resources [10]. Indeed, the training of thinking, especially creative-minded professionals, is an important guarantee of the creation of human capital.

It is known that being aware of the content of the basic concept helps students to study the process of developing creative abilities from a pedagogical point of view in the example of English.

\section{MATERIAL AND METHODS}

According to the lexical meaning, "creativity" means "create", "creator", "creative". The concept has been interpreted differently by researchers. In particular, practical action by the individual (Gorward Gardner) [3, 4-5]; to have a high level of unconventional skills in addition to the thorough knowledge acquired in a particular field (Teresa M. Emabile) [17, 371]; the ability to know, the purpose of which is to create new ideas and to gain a deeper understanding of one's own experience (Erich Fromm) [18]; the intellectual ability of the individual with a relatively stable structural structure (Jean Piaje) [12, 33]; property activated by environmental influences (Vladimir Drujinin) [9, 30]; strengthening knowledge on the basis of the acquisition of knowledge, the elimination of shortcomings and defects, the integration of information in various fields; the ability to form on the basis of general intellect, the individual character of the individual, and the present state of productive thinking (Ellis P. Torrens) [13]; a description that allows to express the individuality of the person (Evgenia Yakovleva) [15, 70]; universal positive creative ability (Oleg Tikhomirov) [14, 5-6]; a set of descriptions characterizing the quality of the thought process (Irina Malakhova) [9, 30]; the birth of extraordinary ideas, deviating from the traditional pattern of thinking, the creative ability to express quick solutions to problematic situations (Tatiana Gritsay, Petr Chernetsov) [4]; the creative ability of the individual, which characterizes the readiness to produce new ideas and is part of the talent as an independent factor (Mahfuza Usmanbaeva) [8, 6-7]; ability to create many ideas of practical value (Turgun Alibaev) $[1$, 15].

V. Moroz, studying the essence of the concept of "creativity", argues that the basis of this term is reflected not the assimilation of information as a basic component of the modern era, but the creation of new ideas [10].

In general, the search for a solution to a particular problem on the basis of creativity involves the creation of many new ideas, the promotion of original views, analysis, the choice of a different, non-standard approach on the basis of comparative study. Creativity in each person and the formation of the qualities that reflect it are based on six important factors.

These are: existing knowledge, intellectual processes organized by the person, the preferred way of thinking in the person, the individual characteristics of the person, the motivation of the person and the influence of the environment to person.

A study of the problem of developing creative ability in an individual has shown that research activities aimed at this goal have a relatively long history. This historical process is 
significant in that the theory of the development of creativity in the individual has been enriched with new ideas in different periods:
1. Graham Wallace 1858-1932 Defines the chronological flow of the creative process (stages such as preparation, "budding", maturation and control)
2. Max Wertheimer 1880-1943 The relation of creativity to cognition is studied; an impulse was created to study the phenomenon of creativity
3. Wolfgang Kyoler 1887-1967
4. Alex Osborne 1888-1966 The structure of the process that produced many ideas was developed; It is based on the method of "mental attack".
5. Joy Paul Gilford 1897-1987 developed the famous theory known as the "Structure of the Intelligence"; a special test has been developed to assess a person's creativity and its level.
6. Berres Frederick Skinner 1904-1990 Based on the behavioral theory of creativity.
7. Arthur Kyostler 1905-1983 The nature of the creative process is studied.

8. Ellis Paul Torrens 1915-2003 Creativity is defined as a process of exposure to a problem; a special test has been developed to assess a person's creativity and its level.

9. Mel Rhodes 1916-1976 More than forty concepts related to creativity have been identified; the first model of creativity was created.

10. George Prince 1918-2009 is based on the method of "Synectics", which encourages creative thinking.

11. William Gordon 1919-2003 also based on the method, which encourages creative thinking.

12. Roger Walcott Sperry 1913-1994 The process of thinking in the right and left hemispheres of the brain (creative thinking in the left hemisphere and logical thinking in the right hemisphere) is medically based.

13. Edward de Bono 1933 Creative ideas are studied as values.

14. Mihai Chiksentmihai 1934 Based on the theory of "flow of ideas".

15. Teresa Amabayl 1950 Creative thinking model based on components such as "Internal motivation", "research experience", "creative thinking skills", "creative environment"

16. Ken Robinson put forward the idea of "Creativity is an individual quality" in 1950-2020.

17. Howard Gardner 1943 Five types of thinking (industry-specific, synthesizing, creative, respective, and ethical thinking) are studied.

18. Sarnoff Mednik 1969 Based on the associative theory of creativity.

\section{DISCUSSION AND CONCLUSION}

The educational process in higher education should be focused on the development of students' creative abilities as a whole. After all, only then will they be able to put into practice the theoretical knowledge acquired by them in general and specialized disciplines. At the same time, "creativity helps a person to develop self-esteem, self-confidence and realize their potential, which leads to a more interesting and effective education" [10].

The most important condition for developing students' creative abilities is to accustom them to thinking: analytical, critical and creative thinking. Creativity allows students to analyze a situation no matter how complex it is, to take a critical approach to events, happenings and processes, to achieve the practical nature of the actions required of them, as well as to present solutions to tasks in several variants.

Like other types of skills, students do not develop creativity on their own. In this case, it is expedient to achieve cooperation between the teacher and the student, or pedagogical and student, non-standard, specific approach to teaching. This is due, on the one hand, to the constant, consistent training of students, 
readiness for emergencies (difficult, complex learning tasks), and on the other hand, teachers' learning tasks are interesting, "attractive" for students (somehow, even the simplest, almost imperceptible) although enriched with the element), their complete freedom in the process of completing tasks is ensured through the elimination of various emotional barriers.

In addition, "creative teaching does not take place in space, it is necessary to create favorable conditions for the development of creativity in both teachers and students. Emphasis is placed on: creating an environment in which the person is free, free from criticism, does not worry about the person (in such cases, many mistakes are usually made), but can feel confident; no matter how illogical, to set a boundary of activity that brings students together in the desired content and language without having to talk or write about everything in a row; encourage the individual to express his or her views openly but amicably about the work of his or her groupmates (criticism should be of practical importance without denying the author's feelings); encourage students' curiosity and "research activity" (the teacher can motivate students by collecting various resources (articles, books, magazines, websites) that can be used later); emphasizing the importance of independent work, because classroom education is only the "tip" of the iceberg, and the main tasks are performed outside the educational institution; manifestation of personality creativity to achieve regularity and systematicity in the process "[16, 7-8].

The creation of favorable conditions in the educational process "serves as a" creative process in the environment of higher education, when the targeted exchange of competencies and values between teachers and students "[11].
It should be noted that it is wrong for teachers to expect students to suddenly have "revolutionary ideas" for creative thinking. As Mali Alan acknowledges in this regard, achieving consistency, regularity, systematization guarantees success. From a psychological point of view, creative ability in students is "first manifested at the motivational-personal, then at the productive (active) level" [5, 189].

Psychologically, physiologically, a constant, consistent repetition of an action allows it to be effective. In this regard, the development of creative abilities in students requires the regular use of tasks of a creative nature in the educational process. $[2,3]$.

Based on the above considerations, it can be concluded that creativity is a personalityspecific ability that represents a multifaceted thinking on a problem, offering unusual, unexpected solutions. The development of creativity in university students, as in any other person, does not happen by itself, it is the regular presentation of creative tasks in the teaching process, consistency, systematization, ensuring their freedom, harmonization of teachers and students. In the history of the development of pedagogical ideas, the problem of developing the creative ability has a special place. The idea of Graham Wallace is the basis of the theory of the development of individual creativity. Dozens of new views have been put forward for more than a hundred years since the idea of $G$. Wallace.

\section{ACKNOWLEDGEMENT}

Thus, the intensification of the industrialization process in the second half of the nineteenth century created the need to study the problem of developing the creative ability of the person. Since the volume and scale of production in the manufacturing industry is not so large, it is not necessary to constantly change in a short period of time in 
order to be unique in terms of their content, quality, design.

In the process of industrialization, the rapid pace of production, the growing number of competing enterprises required continuous research on the composition, quality, design of products, to achieve high efficiency in this regard. The rapid development of production technologies has created favorable conditions for the rapid development of information, services and manufacturing industries. As a result, achieving creative thinking professionals has become a requirement of the times. The development of creative abilities in students contributes to the training of qualified professionals in higher education.

\section{REFERENCES}

1. Aliboev T.Ch. Improving technologies for the development of creative qualities in students in an innovative educational environment (on the example of the subject "Technology"): ped.fanl. on fal.dok. (DPh) ... dis. - Jizzax: 2021 .- 15-b

2. Bose E. How to develop creativity / Per. with him. K.A. Petrosyan. - Rostov n / a: Phoenix, 2008 .-- S. 3.

3. Gardner, Howard. Thinking of the future. Five types of intelligence leading to success in life. - $M$.: Alpina Business Books, 2008. - S. 4-5.

4. Gritsay T.I., Chernetsov P.I. Research of the creativity of high school students // https://cyberleninka.ru/article/n/issledovan ie-kreativnosti-starsheklassnikov.

5. Druzhinin V.N. Cognitive abilities: structure, diagnosis, development. - SPb :: IMATON, 2001 .-- S. 189.

6. Druzhinin V.N. Creativity: nature and development // J. of the Higher School of Economics. - M .: 2005. - No. 3. Series. Psychology. - S. 91-92.
7. Emelyanova O.Ya., Shershen I.V. The phenomenon of creativity: nature, content and development factors // https://bgscience.ru/lib/10607.

8. Creative pedagogy / Textbook. M. H. Usmonbaeva et al. - T.: "Navruz" publishing house, 2020. - 6-7-p.

9. Malakhova I.A. Development of the creativity of schoolchildren in the process of amateur artistic activity: dis ... doctor of pedagogical sciences. - Minsk: 2011 .-- S. 30.

10. Moroz V. V. A creative approach to teaching a professionally oriented foreign language https://cyberleninka.ru/article/n/ kreativnyy-podhod-k-prepodavaniyuprofessionalno-orientirovannogoinostrannogo-yazyka.

11. V. V. Moroz Development of creativity of university students in the process of teaching a foreign language // https://cyberleninka.ru/article/n/razvitiekreativnosti-studentov-universiteta-vprotsesse-obucheniya-inostrannomuyazyku

12. Piaget, Jean. The nature of intelligence // Reader in psychology: psychology of thinking. Compiled by Yu.B. Gippenreiter. M .: AST, 2008 .-- S. 33.

13. Torrance's creativity test. Diagnostics of creative

//https://psycabi.net/testy/577-testthinking kreativnosti-torrensa-diagnostikatvorcheskogo- myshleniya.

14. Tikhomirov O.K. Psychological research of creative activity / Monograph. - M .: Nauka, 2005 -- S. 5-6.

15. Yakovleva E.L. The individuality of the child in the educational process: the development of creativity // J. New 
research in psychology. - $M .: 2009$. - No. 2. - P. 70.

16. Alan, Maley. Overview: Creativity - the what, the why and the how // Creativity in the English language classroom. Edited by Maley Alan and Pechey Nik. - London: British Council, UK, 2015. - P. 6-13.

17. Amabile, M. Tereza. Affect and creativity at work // J. Administrative Science Quarterly. - New-York: 2005. - No. 3 (50). pp. 371.

18. Talk: Erich https://en.wikiquote.org/wiki/Talk:Erich_Fr omm. 